\title{
Comparison of immunoturbidimetric and Lowry methods for measuring concentration of very low density lipoprotein apolipoprotein B-100 in plasma
}

\author{
M H Cummings, G F Watts, P J Lumb, B M Slavin
}

\begin{abstract}
To assess whether the Lowrytetramethylurea method for measuring apolipoprotein B-100 (apo-B) in very low density lipoprotein (VLDL) could be replaced by direct assay of VLDL apo-B using a highly practicable immunological method. Seventy five fasting blood samples were collected from patients attending the lipid clinic at this hospital. Plasma was separated immediately and VLDL isolated by preparative ultracentrifugation at solution density 0.93-1.006 kg/1. Apo-B was precipitated from an aliquot of the VLDL fraction using the tetramethylurea (TMU) technique and protein mass determined by the Lowry method (LM); mean apo-B 83.02 $\mu \mathrm{g} / \mathrm{ml}$ (SD 74.85). Apo-B was also measured in VLDL using direct immunoturbidimetry on the Cobas-Fara analyser; mean apo-B $82 \cdot 32 \mu \mathrm{g} / \mathrm{ml}$ (SD 72-88). There was a very close correlation between methods (immunoturbidimetry $=0.94 . \mathrm{LM}+3.95, \mathbf{r}=0.97, \mathrm{p}<0.001)$. The mean difference between methods (constant error) was small $(0.70 \mu \mathrm{g} / \mathrm{ml})$ and not significant $(p=0.742)$. Random error was $13.01 \mu \mathrm{g} / \mathrm{ml}$ by analysis of variance.

It is concluded that immunoturbidimetry, a more rapid and convenient test, may replace the $L M$ and TMU techniques for measuring VLDL apo-B concentration and that this method could be applied to research studies requiring analysis of large numbers of samples.
\end{abstract}

(F Clin Pathol 1994;47:176-178)

Apo-B is the major structural protein of VLDL and its metabolic products, intermediate density lipoprotein (IDL) and low density lipoprotein (LDL). It is required for the hepatic synthesis and secretion of VLDL $L^{1}$ and therefore determines VLDL transport rates in plasma. Comprehensive study of lipoprotein kinetics requires accurate and rapid measurement of the apolipoprotein B-100 (apo-B) concentration in each lipoprotein fraction. Recently, we needed to measure the apo-B concentration in VLDL to determine VLDL transport rates in stable isotope studies. VLDL is conventionally assayed by the Lowry method (LM) after isolation of apo-B by tetramethylurea (TMU) precipitation. ${ }^{2}$ This procedure is time consuming, requires considerable technical skill to isolate VLDL apo-B, and uses a reagent (TMU) that is potentially harmful. We therefore aimed to assess whether the method could be replaced by direct assay of VLDL apo-B using immunoturbidimetry, a much more convenient and rapid method.

\section{Methods}

We collected 75 fasting blood samples from patients attending the lipid clinic at St Thomas's Hospital into EDTA $(0.1 \mathrm{mg} / \mathrm{l})$ tubes. Plasma was separated immediately and the VLDL fraction was isolated by overlaying $4 \mathrm{ml}$ of plasma with $1 \mathrm{ml}$ of $1.006 \mathrm{~kg} / 1$ sodium chloride density solution and spinning at $37000 \mathrm{rpm}$ (centrifugal force of $147000 \times g$ ) for 16 hours. The supernatant fluid containing VLDL was removed and made up to $2 \mathrm{ml}$ with $1.006 \mathrm{~kg} / \mathrm{l}$ sodium chloride density solution. VLDL apo-B concentration for each patient was then assayed by both methods within 48 hours, after storage of plasma at $4^{\circ} \mathrm{C}$.

\section{LOWRY METHOD (LM)}

The VLDL fraction $(1 \mathrm{ml})$ was added to $1 \mathrm{ml}$ of freshly distilled TMU and after mixing, incubated at $37^{\circ} \mathrm{C}$ for 30 minutes. The apo-B precipitate was separated by centrifuging at $2000 \mathrm{rpm}\left(4^{\circ} \mathrm{C}\right)$ for 30 minutes in a fixed angle rotor. The supernatant fluid was removed by aspiration and $3 \mathrm{ml}$ of an ether/ethanol mix (freshly made 1:3) was added to the precipitate, mixed by vortex, and incubated at $-20^{\circ} \mathrm{C}$ for 12 hours. The solution was re-spun at $2000 \mathrm{rpm}\left(4^{\circ} \mathrm{C}\right)$ for 30 minutes and the supernatant fluid removed by aspiration. Of $0.5 \mathrm{M}$ sodium hydroxide, $2 \mathrm{ml}$ were added to the remaining precipitate and then roller mixed for 12 hours. The sample $(0.5 \mathrm{ml})$ was added to $1.5 \mathrm{ml}$ of freshly prepared Lowry reagent (made by adding $1 \mathrm{ml}$ of $2 \%$ sodium potassium tartrate and $1 \mathrm{ml}$ of $1 \%$ copper sulphate to $100 \mathrm{ml}$ of $2 \%$ sodium carbonate) and $0.5 \mathrm{ml}$ of water. After mixing, the sample was allowed to stand for 10 minutes before the addition of $0.5 \mathrm{ml}$ Folin and Ciocalteu's phenol reagent working solution (Sigma Diagnostics, St Louis, Missouri, USA). The sample was mixed and placed in the dark for 30 minutes. Absorbance was then read at 660 nm using a Phillips PU8700 Series UV/Visable spectrophotometer (Pye Unicam Ltd, Cambridge, England). The apo-B concentration $(\mu \mathrm{g} / \mathrm{ml})$ was determined from 
a standard curve (concentration range 0-192 $\mu \mathrm{g} / \mathrm{ml}$ ) prepared from a stock bovine albumin standard, $400 \mathrm{mg} / \mathrm{ml}$ (Sigma) was used as the protein standard. Urinary protein standard (Randox Laboratories Ltd. Crumlin, Co. Antrim, Ireland) diluted 1 in 12.5 and 1 in 25 , was used as a working quality control. Interassay $\mathrm{CV}=3 \%$, sensitivity $=$ $7 \mu \mathrm{g} / \mathrm{ml}$.

\section{IMMUNOTURBIDIMETRY}

The materials used were anti-human apo-B antibody (diluted in 5\% polyethylene glycol 6000 solution and $0 \cdot 2 \%$ Tween), a protein standard (reference standard apoproteins human) and quality control material (normal control apoproteins human) as supplied in a commercial kit (Immunoturb Kit, Immuno Ltd., Dunton Green, Kent, England). The analytical procedure was fully automated (Cobas-Fara Analyser, Hoffmann-La Roche AG, Basel, Switzerland): $20 \mu$ l of the VLDL fraction was added to $200 \mu \mathrm{l}$ of antibody solution and the quantification of apo-B $(\mu \mathrm{g} / \mathrm{ml})$ was determined by reading the change in absorption level of the sample at $340 \mathrm{~nm}$, and apo-B being derived with reference to a standard curve (concentration range $0-310 \mu \mathrm{g} / \mathrm{ml}$ ). Interassay $\mathrm{CV}=4 \%$, sensitivity $=7 \cdot 75 \mu \mathrm{g} / \mathrm{ml}$.

VLDL apo-B concentration obtained by immunoturbidimetry was compared with the LM by simple linear regression analysis. Systematic error was evaluated as the mean difference between methods using a paired $t$ test. Random error between methods was assessed as the residual standard deviation by a two way analysis of variance. ${ }^{3}$ Because the absolute variation between methods increased with the VLDL apo-B concentration, we assessed systematic error for low $(<80 \mu \mathrm{g} / \mathrm{ml})$ and high $(>80 \mu \mathrm{g} / \mathrm{ml})$ concentrations.

\section{Results}

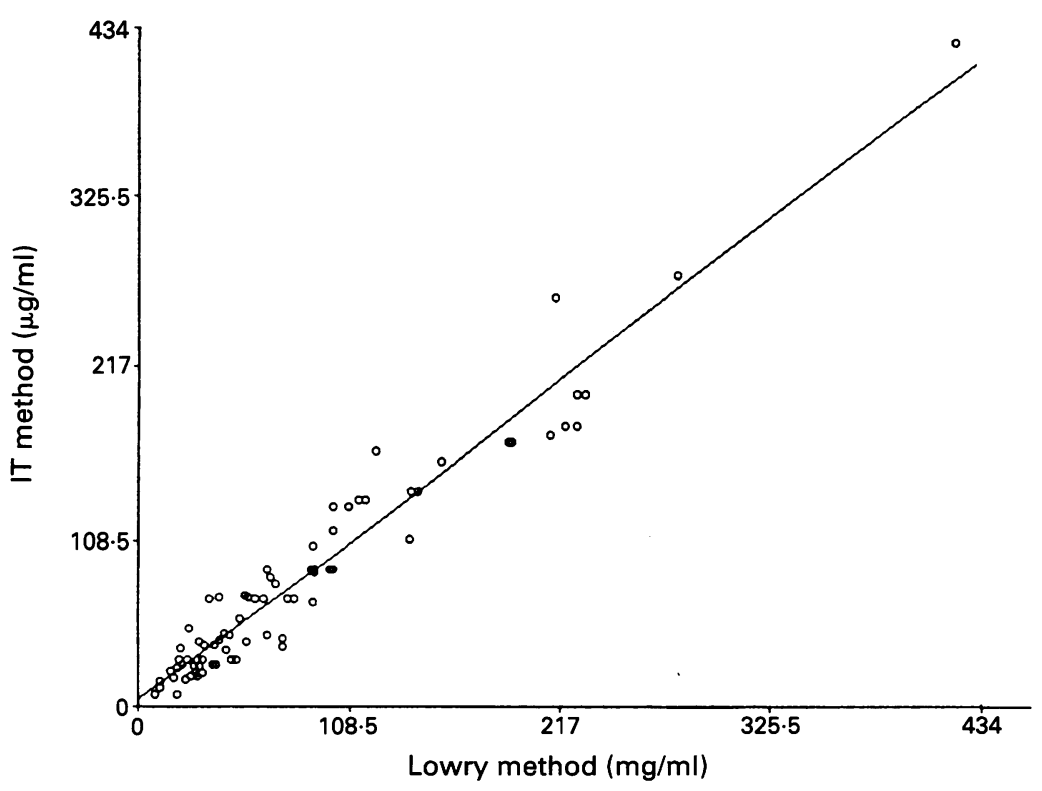

The plasma concentration of VLDL apo- $B(\mu \mathrm{g} / \mathrm{ml})$ measured by the Lowry method plotted against the plasma concentration of $V L D L$ apo-B $(\mu \mathrm{g} / \mathrm{ml})$ determined by immunoturbidimetry.
Statistical comparison of plasma concentration of $V L D L$ apolipoprotein $B-100(\mu \mathrm{g} / \mathrm{ml})$ measured by the Lowry method and by immunoturbidimetry

\begin{tabular}{clll}
\hline & $\begin{array}{l}\text { Mean } \\
\text { difference } \\
\text { between } \\
\text { methods }\end{array}$ & $\begin{array}{l}\text { 95\% Confidence } \\
\text { intervals for } \\
\text { mean difference }\end{array}$ & $\begin{array}{l}\text { Random } \\
\text { error }\end{array}$ \\
\hline $\begin{array}{l}\text { All samples } \\
\text { (n }=75) \mu \mathrm{g} / \mathrm{ml}\end{array}$ & $\begin{array}{l}0.70 \\
\text { (SD 18.37) }\end{array}$ & -3.46 to 4.86 & 13.01 \\
$\begin{array}{c}\text { Mean VLDL apo- } \\
\text { B }<80 \mu \mathrm{g} / \mathrm{ml} \\
(\mathrm{n}=49)\end{array}$ & $\begin{array}{l}0.25 \\
(\mathrm{SD} 14.11)\end{array}$ & -3.70 to 4.20 & 10.09 \\
$\begin{array}{c}\text { Mean VLL apo- } \\
\text { B }>80 \mu \mathrm{g} / \mathrm{ml} \\
(\mathrm{n}=26)\end{array}$ & $\begin{array}{l}5.13 \\
\text { (SD 33.91) }\end{array}$ & -8.57 to 18.83 & 17.40 \\
\hline
\end{tabular}

The figure plots the VLDL apo-B concentration obtained by the LM against that determined by immunoturbidimetry. This illustrates a close correlation between methods $(r=0.97, p<0.001)$ and by simple linear regression analysis, immunoturbidimetry $=0.94 . \mathrm{LM}+3 \cdot 95$. The table shows the mean difference between methods, the $95 \%$ confidence intervals of the mean difference, and random variation for all the samples and for samples of low $(<80 \mu \mathrm{g} / \mathrm{ml})$ and high $(>80 \mu \mathrm{g} / \mathrm{ml})$ VLDL apo-B concentration. The data showed that systematic error (the degree of bias) was small and there was no significant analytical difference $(p=0.742$ for all samples; $\mathrm{p}=0.901$ for VLDL apo-B $<80 \mu \mathrm{g} / \mathrm{ml} ; \mathrm{p}=0.448$ for VLDL apo-B $>80 \mu \mathrm{g} / \mathrm{ml}$ ).

\section{Discussion}

This is the first report to compare plasma VLDL apo-B concentration determined by immunoturbidimetry with the standard Lowry-TMU method. Our data indicate that there was an excellent correlation between the two procedures. The mean differences between methods was small and not significant and there was minimal random error. The precision and sensitivity also compared favourably with the Lowry-TMU method. Although we analysed our VLDL samples within 48 hours of ultracentrifugation, we have already found (unpublished data) that there is no significant change in apolipoprotein concentration measured by immunoturbidimetry after storage of samples at $-20^{\circ} \mathrm{C}$ for up to eight weeks.

Previous work has shown that immunoturbidimetry is a precise, specific, and highly sensitive method for measuring plasma total apo-B concentration ${ }^{4}$ and that it compares well with nephelometry and radial immunodiffusion (RID). ${ }^{5}$ However, immunoturbidimetry has not been applied to determine apo-B concentration in VLDL. Similarly, although other methods are in routine use for measuring plasma total apo-B concentration, there is limited information on their performance for determining apo-B concentration in lipoprotein fractions. A sensitive, reproducible, enzyme linked immunosorbent assay (ELISA) for measuring plasma apo-B concentration has been reported by Ordovas et $a l^{6}$ and seemed to produce similar levels to RID, but the method was not extended to 
estimating VLDL apo-B. Unfortunately, the full automation of ELISA is difficult and the procedure requires high dilution of samples. ${ }^{7}$ RID requires small dilution of samples but large amounts of antisera and the procedure cannot be suitably automated. ${ }^{8}$ One study compared VLDL apo-B concentration determined by electroimmunoassay (EIA) and the Lowry method; it showed that although there was no overall significant systematic difference between the two methods, the technique of EIA was affected by the electrical charge of the protein being measured ${ }^{9}$ which may lead to inaccuracies.

The measurement of plasma apo-B concentration by immunoturbidimetry has been criticised as being extremely sensitive to the turbidity of the sample. ${ }^{10}$ As this method relies on the absorbance of light as an endpoint, this may lead to inaccuracies in quantification due to direct interference by large lipoproteins (the so-called "matrix effect"). Our results show, however, that there is good correlation between VLDL apo-B concentration when measured by the LM and immunoturbidimetry.

In this comparison of methods, we used the isolation of VLDL apo-B by TMU and quantification by the LM as the "gold standard" technique. This would seem to be a reasonable conclusion based on the work of Kane $e t \mathrm{al}^{2}$ who found the recovery of protein in the seven species of apoprotein of VLDL precipitated by TMU accounted for over $97 \%$ of the total in normolipidaemic people and in most patients with endogenous hyperlipidaemia. Although there is no significant bias between methods and these may be used interchangeably, there may be certain instances at low VLDL apo-B concentration $(<80 \mu \mathrm{g} / \mathrm{ml})$ where caution is needed in interpreting results in view of the degree of random error reported. We are currently investigating this problem but intuitively believe this to be due to the inaccuracies associated with the LM because of incomplete recovery of VLDL apo-B following precipitation with TMU.

When measuring apo-B concentrations by the immunoturbidimetry method, it has been assumed that the immune complexes formed are required to be of relatively constant size for their light scattering intensity to be proportional to the concentration of antigen. Theoretically, therefore, immunoturbidimetry is likely to have least interference when measuring apo-B concentration of individual lipoprotein fractions (as opposed to plasma apo-B concentration) and this is supported by our preliminary data suggesting that this method may also apply to quantification of IDL and LDL apo-B.

In summary, there is an excellent correlation between immunoturbidimetry and the LM for measuring VLDL apo-B concentration. Immunoturbidimetry is a readily automatable and rapid method with a high degree of precision and accuracy. We conclude that immunoturbidimetry would be a useful and more convenient research method for measuring VLDL apo-B concentration as an alternative to LM-TMU, particularly when large numbers of samples need to be analysed.

Dr $M$ Cummings is in receipt of a research grant from the Special Trustees for St Thomas's Hospital.

Young SG. Recent progress in understanding apolipoprotein B. Circulation 1989;80:219-33.

2 Kane JP, Sata T, Hamilton RL, et al. Apoprotein composition of very low density lipoproteins of human serum. Clin Invest 1975;56:1622-34.

3 Armitage P, Berry G. Statistical methods in medical research. 2nd edn. Oxford: Blackwell Scientific Publications, 1987:214-22.

4 Mount JN, Kearney EM, Rosseneu M, et al. Immunoturbidimetric assays for serum apolipoproteins $\mathrm{A} 1$ and $\mathrm{B}$ using Cobas Bio centrifugal analyser. $₹$ Clin Pathol 1988;41:471

5 Brustolin D, Maierna $M$, Aguzzi $F$, et al. Immunoturbidimetric method for routine determinations of apolipoproteins A-1 and B. Clin Chem 1991;37:742-7.

6 Ordovas JM, Peterson JP, Santaniello P, et al. Enzymelinked immunosorbent assay for human plasma linked immunosorbent assay for human

7 Rifai N, Russell Warnick G. Clinical significance and measurements of apolipoproteins A1 and B concentrations. In: Methods for clinical laboratory measurement of lipid and lipoprotein risk factors. Washington, DC, AACC Press, 1991:87-100.

8 Bhatnagar D, Durrington PN. Clinical value of apolipoprotein measurement. Ann Clin Biochem 1991;28. protein

9 Calvert GD, Yeates RA, Roeger DC. Electroimmunoassay of a subunit protein in a macromolecular complex (apolipoprotein B in human very low density lipoprotein); implications for other electroimmunoassay systems. Clin Chim Acta 1979;97:135-42.

10 Labeur C, Shepherd J, Rosseneu M. Immunological assays of apolipoproteins in plasma: Methods and instrumentation. Clin Chem 1990;4:591-7. 